\title{
Acetylsalicylic Acid and Labeling of Blood Constituents with Technetium-99m
}

\author{
Adenilson de Souza da Fonseca ${ }^{1 *}$, Jacques Natan Grinapel Frydman ${ }^{2}$, Vanessa Câmara da \\ Rocha $^{2}$ and Mario Bernardo-Filho ${ }^{2}$ \\ ${ }^{1}$ Departamento de Farmacologia e Psicobiologia; ${ }^{2}$ Departamento de Biofísica e Biometria; Instituto de Biologia \\ Roberto Alcantara Gomes; Universidade do Estado do Rio de Janeiro; Av. 28 de Setembro, 87, fundos; $5^{\circ}$ andar; \\ 20551-030; Rio de Janeiro - RJ - Brasil
}

\begin{abstract}
Acetylsalicylic acid is the drug most used an anti-inflammatory agent and for secondary prevention of thrombotic phenomenon. Drugs can modify the labeling of blood constituents with technetium-99m (99mTc). The aim of this work was to evaluate the effect of in vitro or in vivo assays with acetylsalicylic acid on the labeling of the blood constituents with 99mTc. In vitro assay was performed with samples of whole blood from Wistar rats incubated with acetylsalicylic acid $(1.0 \mathrm{mg} / \mathrm{ml})$ for one hour before the $99 \mathrm{mTc}$-labeling process. For in vivo assay, Wistar rats were treated with acetylsalicylic acid $(1.5 \mathrm{mg} / \mathrm{kg})$ during one hour, and the whole blood was withdrawn for the $99 m$ Tc-labeling process. Saline was used in control groups. Data showed that the fixation of $99 m$ Tc to the blood constituents was not significantly ( $p>0.05)$ modified in in vitro and in vivo assays with acetylsalicylic acid, at least not when the experiments were carried out with the doses normally used in human beings.
\end{abstract}

Key words: Acetylsalicylic Acid; Blood Constituents; Technetium-99m

\section{INTRODUCTION}

Acetylsalicylic acid is the most widely used drug for antipyretic, analgesic, anti-inflammatory action and for the secondary prevention of ischemic events in the brain, heart and peripheral circulation (Ruth and Calverley, 1994; Antithrombotic Trialists' Collaboration, 2002; De La Cruz et al., 2004). Its antipyretic, analgesic and antiinflammatory actions are based on irreversible inhibition of the cyclooxygenase enzyme that is responsible for the prostaglandin synthesis and some autacoids (Catella-Lawson, 2001; Amann and Peskar, 2002; Aude and Mehta, 2002). The acetylsalicylic acid effects on thrombotic phenomenon seem to be mainly a result of its antiplatelet action (Grotta et al., 1985; CatellaLawson, 2001).

It has been postulated that the ability of acetylsalicylic acid to prevent cerebrovascular accidents is related to the inhibition of oxidative stress (Sagone et al., 1987; Guerrero et al., 2004). In this context, it was demonstrated that acetylsalicylic acid reduces hypercholesterolemic atherosclerosis by decreasing the generation of oxyradicals (Prasad et al., 2003). However, acetylsalicylic acid can cause adverse gastrointestinal effects such as gastric ulceration, erosive gastritis, gastrointestinal hemorrhage and exacerbation of peptic ulcer symptoms at therapeutic doses (Bollini et al., 1992; Langman et al., 1994). In addition, other adverse effects related

\footnotetext{
${ }^{*}$ Author for correspondence
} 
to $\mathrm{pH}$ and ion balance such as respiratory alkalosis with increased $\mathrm{Na}^{+}, \mathrm{K}^{+}$and bicarbonate excretion (Lauwerys and Bernard, 1989; Nuyts et al., 1989) can be observed when analgesic or antiinflammatory doses of acetylsalicylic acid are used.

Red blood cells labeled with technetium-99m (99mTc-RBC) have been used in nuclear medicine in a number of evaluation procedures for the gastrointestinal bleeding sites (Wong et al., 2004; Zaman et al., 2004; Olds et al., 2005), peripheral arterial blood flow (Harel et al., 2005), hepatic hemangiomas (Artiko et al., 2004; Verdu et al., 2005), renal carcinoma (Cortes et al., 2003) and splenic reticuloendothelial system (Jin et al., 2004; Slart et al., 2004).

Data have shown that some drugs can modify the labeling of blood constituents, such as the RBC, with $99 \mathrm{mTc}$ and should alter the results obtained in the daily routine procedures in nuclear medical laboratories (Hladik III et al., 1987; Capriles et al., 2002; de Oliveira et al., 2002; Frydman et al., 2004; Fonseca et al., 2005). The aim of this work was to investigate the in vitro and in vivo effects of acetylsalicylic acid on the labeling of blood constituents with $99 \mathrm{mTc}$.

\section{MATERIALS AND METHODS}

\section{Animals}

Adult male Wistar naive rats (3-4 months of age, body weight $250-350 \mathrm{~g}$ ) were housed, five per cage, in an environment controlled room with light/dark cycle conditions (12 hours light/12 hours dark; lights on at 6:00 a.m.). Animals had free access to water and food and ambient temperature was kept at $25 \pm 2^{\circ} \mathrm{C}$. Experiments were conducted in accordance with the Department Committee of Animal Care.

\section{Drugs}

Acetylsalicylic acid used in this study was purchased from Bayer (Brazil).

\section{In vitro assay with acetylsalicylic acid}

Heparinized samples $(0.5 \mathrm{ml}, \mathrm{n}=6)$ of whole blood were incubated with $100 \mu \mathrm{l}$ of saline acetylsalicylic acid solution at $1.0 \mathrm{mg} / \mathrm{ml}$ for 1 hour at room temperature before the $99 \mathrm{mTc}$ labeling procedure. Samples of whole blood (0.5 $\mathrm{ml}, \mathrm{n}=6)$ incubated with saline solution $(\mathrm{NaCl}$ $0.9 \%$ ) were used as the control group.

\section{In vivo assay with acetylsalicylic acid}

The animals $(\mathrm{n}=5)$ were treated by gavage during 1 hour with $1.5 \mathrm{mg} / \mathrm{kg}$ acetylsalicylic acid dose, and, heparinized whole blood was withdrawn for 99 mTc labeling procedure. Animals $(n=5)$ treated with saline solution were used as control group.

\section{9mTc labeling of blood constituents}

After in vitro or in vivo treatment with acetylsalicylic acid, the samples $(0.5 \mathrm{ml})$ of whole blood were incubated with stannous chloride (1.2 $\mu \mathrm{g} / \mathrm{ml}$ ) (Sigma Chemical Co., St Louis, USA) during 1 hour. After this period, 99mTc $(100 \mu \mathrm{l}$, $37 \mathrm{MBq} / \mathrm{ml}$ ), as sodium pertechnetate, recently milked from a molybdenium-99/technetium-99m generator (Instituto de Pesquisas Energéticas e Nucleares, Comissão Nacional de Energia Nuclear, São Paulo, Brazil), was added and the incubation continued for another 10 minutes. These samples were centrifuged and plasma $(\mathrm{P})$ and blood cells (BC) were separated. Samples $(20 \mu \mathrm{l})$ of $\mathrm{P}$ and $\mathrm{BC}$ were precipitated in $1.0 \mathrm{ml}$ of trichloroacetic acid (5\%), and soluble (SF) and insoluble fractions (IF) were separated. The radioactivity in $\mathrm{P}, \mathrm{BC}$, IF-P, SF-P, IF-BC and SF$\mathrm{BC}$ were determined in a gamma counter (Autogamma, Packard Instrument Company, Illinois, USA). The percentage of radioactivity (\%ATI) was calculated, as previously described (BernardoFilho et al., 1994).

\section{Statistical analysis}

Data are reported as means \pm SD of \%ATI, and the treated and control groups were compared by the Student $t$ test with a significance level $p<0.05$. InStat Graphpad software was used to perform statistical analysis (GraphPad InStat version 3.00 for Windows 95, GraphPad Software, San Diego California, USA).

\section{RESULTS}

The \%ATI in P, BC, IF-P, SF-P, IF-BC and SF$\mathrm{BC}$ from whole blood treated in vitro with acetylsalicylic acid $(1.0 \mathrm{mg} / \mathrm{ml})$ are shown in Fig. 1. The data presented in this figure show that, in this in vitro assay with the drug at the concentration used, small, but not significant 
( $\mathrm{p}>0.05)$, alterations in the uptake of $99 \mathrm{mTc}$ by fractions of plasma and blood cells were found. plasma, blood cells and insoluble and soluble

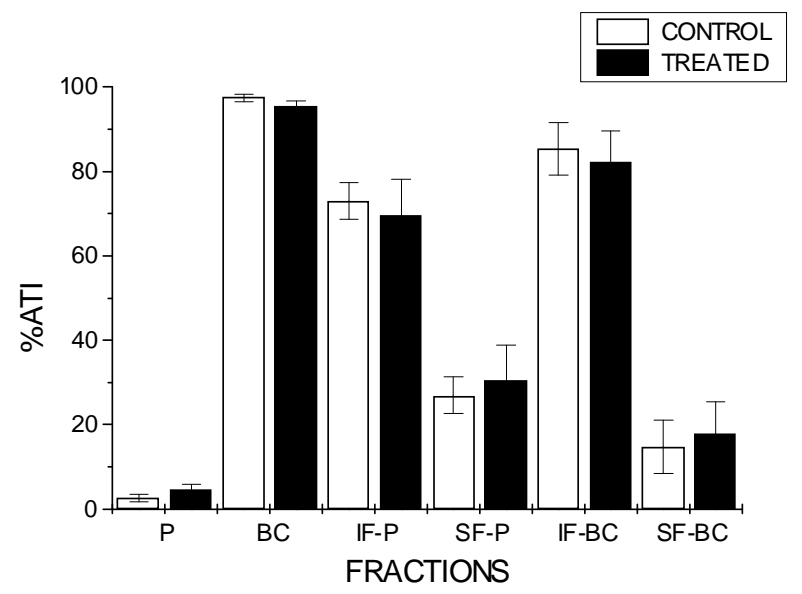

Figure 1 - \%ATI in different fractions of blood constituents in in vitro assay with acetylsalicylic acid. Heparinized samples $(0.5 \mathrm{ml}, \mathrm{n}=6)$ of whole blood were incubated with $100 \mu \mathrm{l}$ of acetylsalicylic acid solution $(1.0 \mathrm{mg} / \mathrm{ml})$ during 1 hour at room temperature. After this period, the labeling procedure was performed and \%ATI was calculated. Whole blood incubated with saline solution constituted the control group $(n=6)$. Plasma $(P)$, blood cells $(B C)$, insoluble fraction of plasma (IF-SF), soluble fraction of plasma (SF-P), insoluble fraction of blood cells (IF-BC) and soluble fraction of blood cells (SF-BC).

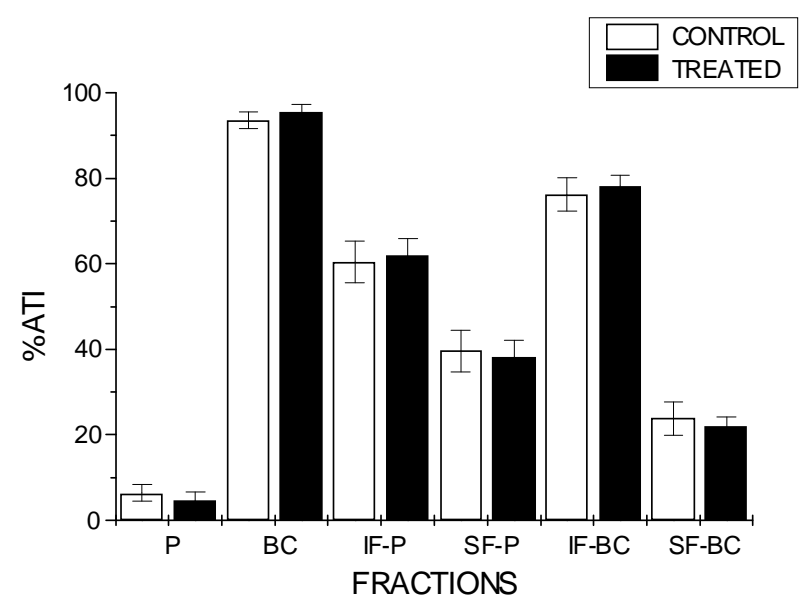

Figure 2 - \%ATI in different fractions of blood constituents in in vivo assay with acetylsalicylic acid. The animals $(\mathrm{n}=5)$ were treated with a $1.5 \mathrm{mg} / \mathrm{kg}$ dose of acetylsalicylic acid during 1 hour. Heparinized whole blood was withdrawn, the labeling procedure was performed, and the \%ATI was calculated. Animals treated with saline solution $(\mathrm{n}=5)$ constituted the control group Plasma $(\mathrm{P})$, blood cells $(\mathrm{BC})$, insoluble fraction of plasma (IF-SF), soluble fraction of plasma (SF-P), insoluble fraction of blood cells (IF-BC) and soluble fraction of blood cells (SF-BC). 
The \%ATI in P, BC, IF-P, SF-P, IF-BC and SF$\mathrm{BC}$ from whole blood of animals treated in vivo during 1 hour with acetylsalicylic acid $(1.5 \mathrm{mg} / \mathrm{kg})$ can be seen in Fig.2. The data presented in this figure indicate that the in vivo treatment with this drug at the concentration used did not significantly ( $>0.05$ ) modify the uptake of $99 \mathrm{mTc}$ by plasma, blood cells and insoluble and soluble fractions of plasma and blood cells.

\section{DISCUSSION}

Therapeutic drugs can modify the nature or amount of the $99 \mathrm{mTc}$-radiopharmaceutical bound to blood constituents and result in an unexpected behavior of the radiopharmaceutical (Hladik III et al., 1987; Hesslewood and Leung, 1994; Sobal and Sinzinger, 2001; Welling et al., 2002; Fonseca et al., 2005). Thus, the evaluation of the influence of drugs on the fixation of $99 \mathrm{mTc}$ in blood constituents is important. However, the data from these studies are relatively scarce, and the effects of pharmacologically active agents on the diagnostic by radiopharmaceuticals can be evaluated.

The data obtained in this work showed that acetylsalicylic acid, at a concentration similar to that used in anti-inflammatory therapy, as antipyretic or as an analgesic drug in humans, did not modify the fixation of $99 \mathrm{mTc}$ to the blood constituents of rats (Figs. 1 and 2).

Other data showed that acetylsalicylic acid can decrease the labeling efficiency of white blood cells (Ellis and Sampson, 1999) and that salicylate treatment may be interrupted one week before initiation of a thyroid uptake study with radioiodine (Hladik III et al., 1987).

The lowest effective plasma concentration of acetylsalicylic acid is about $150 \mu \mathrm{g} / \mathrm{ml}$, and, at plasma concentrations as high as $350 \mu \mathrm{g} / \mathrm{ml}$, toxic effects such as tinnitus and hyperventilation can occur (Chalasani et al., 1996; Porto Arceo, 2003). Thus, the results obtained in this work showed that acetylsalicylic acid in the plasma concentrations found in humans should not alter the uptake of the $99 \mathrm{mTc}$ by the blood constituents studied.

In the $99 \mathrm{mTc}-\mathrm{RBC}$ labeling procedure, stannous ion $\left(\mathrm{Sn}^{+2}\right)$ is used as the reducing agent, so compounds or conditions that interfere with its action can alter the fixation of $99 \mathrm{mTc}$ on these constituents (Hladik III et al., 1987; BernardoFilho et al., 1994).

Several effects of acetylsalicylic acid have been associated with its antioxidant properties (Steer et al., 1997; Wu et al., 2002). However, other authors have shown that, when this drug is given orally, its main metabolite is salicylic acid, which presents an antioxidant effect higher than that of acetylsalicylic acid (Guerrero et al., 2004). Thus, under the conditions used in this study, the absence of an effect of in vitro or in vivo acetylsalicylic acid treatment on uptake of $99 \mathrm{mTc}$ by blood constituents may be related to the small antioxidant effect of this drug on stannous ion. In addition, the absence of alterations in $99 \mathrm{mTc}$ fixation in blood constituents may be influenced by the fact that the half-life of salicylic acid in human plasma is about 15 minutes (Needs and Brook, 1985), and, in this study, a higher treatment period (1 hour) was used in rats.

In conclusion, the data presented in this work showed that in vitro and in vivo treatment with acetylsalicylic acid at the concentrations usually found in the plasma of human beings did not modify the labeling of blood constituents with $99 \mathrm{mTc}$. Although the experiments were carried out with rats, it is possible to suggest that acetylsalicylic acid at therapeutic doses should not interfere with the procedure in nuclear medicine involving the labeling of blood constituents with $99 \mathrm{mTc}$.

\section{RESUMO}

Ácido acetilsalicílico é a droga mais usada como antiinflamatório e para prevenção de fenômenos trombóticos. Drogas podem modificar a marcação de constituintes sangüíneos com tecnécio-99m $(99 \mathrm{mTc})$. O objetivo deste trabalho foi avaliar o efeito do ácido acetilsalicílico in vitro ou in vivo na marcação dos constituintes sangüíneos com $99 \mathrm{mTc}$. Ensaios in vitro foram realizados com amostras de sangue total de ratos Wistar incubadas com ácido acetilsalicílico $(1.0 \mathrm{mg} / \mathrm{ml}) 1$ hora antes do processo de marcação com $99 \mathrm{mTc}$. Para ensaios in vivo, ratos Wistar foram tratados com ácido acetilsalicílico $(1.5 \mathrm{mg} / \mathrm{kg})$ durante 1 hora e, em seguida, o sangue total foi retirado para o processo de marcação com $99 \mathrm{mTc}$. Salina foi usada nos grupos controles. Dados mostraram que nos ensaios in vitro $\mathrm{e}$ in vivo com ácido acetilsalicílico, a fixação do $99 \mathrm{mTc}$ nos 
constituintes sangüíneos não foi significativamente ( $p>0.05)$ modificada, pelo menos, quando os experimentos foram realizados com doses normalmente usadas em humanos.

\section{REFERENCES}

Amann, R. and Peskar, B. A. (2002), Antiinflammatory effects of aspirin and sodium salicylate. Eur. J. Pharmacol., 447, 1-9.

Antithrombotic Trialists' Collaboration, meta-analysis of randomised trials of antiplatelet therapy for prevention of death, myocardial infarction, and stroke in high risk patients. (2002), Br. Med. J., 324, 71-86

Artiko, V.; Obradovic, V.; Petrovic, M.; Perisic-Savic, M. and Suvajdzic, N. (2004), Hemangioma of the spleen confirmed by blood pool scintigraphy. Clin. Nucl. Med., 29, 670-671.

Aude, Y. W. and Mehta, J. L. (2002), Nonplateletmediated effects of aspirin. Drugs Today (Barc), 38, 501-507.

Bernardo-Filho, M.; Gutfilen, B. and Maciel, O. S. (1994), Technetium ${ }^{-99 m}$ binding on plasma proteins and red blood cells: role of various precipitating agents. Biomed. Lett., 50, 17-24.

Bollini, P.; Garcia Rodriguez, L. A.; Perez Gutthann, S. and Walker, A. M. (1992), The impact of research quality and study design on epidemiologic estimates of the effect of nonsteroidal anti-inflammatory drugs on upper gastrointestinal tract disease. Arch. Intern. Med., 152, 1289-1295.

Capriles, P. V.; Dias, A. P.; Costa, T. E.; Oliveira, M. B.; Faria, M. V.; Moura, E. G.; Abreu, B. A. and Bernardo-Filho, M. (2002), Effect of eggplant (Solanum melongena) extract on the in vitro labeling of blood elements with technetium ${ }^{-99 m}$ and on the biodistribution of sodium pertechnetate in rats. Cel. Mol. Biol., 48, 771-776.

Catella-Lawson, F. (2001), Vascular biology of thrombosis: platelet-vessel wall interactions and aspirin effects. Neurology, 57 : (Supp. 2), S5-S7.

Chalasani, N.; Roman, J. and Jurado, R. L. (1996). Systemic inflammatory response syndrome caused by chronic salicylate intoxication. South Med. J., 89, 479-482.

Cortes, J.; Alonso, J. I.; Ruiz-Oliva, F.; Alvarez, S.; Ormijana, J. S.; Caton, B. and Alcorta, P. (2003), Renal cell carcinoma detected on Tc-99m-labeled red blood cell imaging. Clin. Nucl. Med., 28, 920-922.

De La Cruz, J. P.; Guerrero, A.; González-Correa, J. A.; Arrebola, M. M. and Sánchez de al Cuesta, F. (2004), Antioxidant effect of acetylsalicylic and salicylic acid in rat brain slices subjected to hypoxia. J. Neurosci. Res., 75, 280-290.
Ellis, B. L. and Sampson, C. B. (1999), Radiolabelling of blood cells-theory and practice. In: Sampson, C. B. (Ed.). Textbook of radiopharmacy - theory and practice. Baltimore Gordon and Breach Science Publishers. pp. 83-104.

Fonseca, A. S.; Frydman, J. N. G.; Santos, R. and Bernardo-Filho, M. (2005), Influence of antipyretic drugs on the labeling of blood elements with technetium $^{-99 m}$. Acta Biol. Hung., 56, 274-282.

Frydman, J. N. G.; Oliveira, M. B. N.; Santos, A. E. O.; Fonseca, A. S.; Santos, R. and Bernardo-Filho, M. (2004), Influence of methylxanthines on the labeling of blood elements with ${ }^{99 \mathrm{~m}}$ Technetium. Pak. J. Biol. Sci., 4, 521-524.

Galati, G.; Tafazoli, S.; Sabzevari, O.; Chan, T. S. and O'Brien, P. J. (2002), Idiosyncratic NSAID drug induced oxidative stress. Chem. Biol. Interact., 142, $25-41$.

Grotta, J. C.; Lemak, N. A.; Gary, H.; Fields, W. S. and Vital, D. (1985), Does platelet antiaggregant therapy lessen the severity of stroke? Neurology, 35, 632-636.

Guerrero, A.; González-Correa, J. A.; Arrebola, M. M.; Muñoz-Marín, J.; Sánchez de La Cuesta, F. and De La Cruz, J. P. (2004), Antioxidant effects of a single dose of acetylsalicylic acidand salicylic acid in rat brain slices subjected to oxygen-glucose deprivation in relation with its antiplatelet effect. Neurosci. Lett., 328, 153-156.

Harel, F.; Dupuis, J.; Benelfassi, A.; Ruel, N. and Gregoire, J. (2005), Radionuclide plethysmography for non-invasive evaluation of peripheral arterial blood flow. Am. J. Physiol. Heart Circ. Physiol. [in press].

Hesslewood, S. and Leung, E. (1994), Drug Interactions with radiopharmaceuticals. Eur. J. Nucl. Med., 21, 348-356.

Hladik III, W. B.; Ponto, J. A.; Lentle, B. C. and Laven, D. L. (1987), Iatrogenic alterations in the biodistribution of radiotracers as a result of drug therapy: reported instances. In: Hladik III, W. B.; Saha, G. B. and Study, K. T. (Eds.). Essentials of Nuclear Medicine Sciences. Sydney : Williams and Wilkins. pp. 189-219.

Jin, R. B.; Ma, X. L.; Wen, J. L. and Tang, W. J. (2004), Application of radionuclide imaging to hepatic impact injury in rabbits. Chin. J. Traumatol., 7, 45-48.

Langman, M. J.; Weil, J.; Wainwright, P.; Lawson, D. H.; Rawlins, M. D.; Logan, R. F.; Murphy, M.; Vessey, M. P. and Colin-Jones, D. G. (1994), Risks of bleeding peptic ulcer associated with individual non-steroidal anti-inflammatory drugs. Lancet, 343 : (8905), 1075-1078.

Lauwerys, R. and Bernard, A. (1989), Preclinical detection of nephrotoxicity: description of the tests and appraisal of their health significance. Toxicol. Lett., 46, 13-29. 
Nigri, F.; Oliveira, M. B. and Bernardo-Filho, M (2002), Assessment of the effect of antiseizure drugs on the labeling process of red blood cells and plasma proteins with technetium ${ }^{-99 m}$. Cell. Mol. Biol. (Noisyle-grand), 48, 793-801.

Needs, C. J. and Brooks, P. M. (1985), Clinical pharmacokinetics of the salicylates. Clin. Pharmacokinet., 10, 164-177.

Nuyts, G. D.; Elseviers, M. M. and De Broe, M. E. (1989), Health impact of renal disease due to nephrotoxicity. Toxicol. Lett., 46, 31-44.

Olds, G. D.; Cooper, G. S.; Chak, A.; Sivak Jr., M. V.; Chitale, A. A. and Wong, R. C. (2005), The yield of bleeding scans in acute lower gastrointestinal hemorrhage. J. Clin. Gastroenterol., 39, 273-277.

Oliveira, J. F.; Avila, A. S.; Braga, A. C.; Oliveira, M. B.; Boasquevisque, E. M.; Jales, R. L.; Cardoso, V. N. and Bernardo-Filho, M. (2002), Effect of extract of medicinal plants on the labeling of blood elements with Technetium $^{-99 m}$ and on the morphology of red blood cells: I--a study with Paullinia cupana. Fitoterapia, 73, 305-312.

Porto Arceo, J. A. (2003), Special features of NSAID intolerance in children. Allergol. Immunopathol. (Madr)., 31, 109-125.

Ruth, G. J. and Calverley, D. C. (1994), Aspirin, platelets and thrombosis: theory and practice. Blood, 83, 885-898.

Sagone, A. L. and Husney, R. M. (1987), Oxidation of salicylates by stimulated granulocytes: evidence that these drugs act as free radical scavengers in biological systems. J. Immunol., 138, 2177-2183.

Slart, R. H.; Phan, T. T.; Talsma, M. D. and Jager, P. L. (2004), Different splenic uptake of $\mathrm{Tc}^{-99 \mathrm{~m}}$ sulfur colloid and $\mathrm{Tc}^{-99 \mathrm{~m}}$ heat-denatured red blood cells in an infant with complete situs inversus. Clin. Nucl. Med., 29, 590-591.

Sobal, G. and Sinzinger, H. (2001), Methylene blueenhanced stability of $\left({ }^{99 \mathrm{~m}} \mathrm{Tc}\right) \mathrm{HMPAO}$ and simplified quality control--a comparative investigation. Appl. Radiat. Isotopes, 54, 633-636.

Steer, K. A.; Wallace, T. M.; Bolton, C. H. and Hartog, M. (1997), Aspirin protects low density lipoprotein from oxidative modification. Heart, 77, 333-337.
Verdu, J.; Martinez, A.; Anton, M. A.; Munoz, J. M.; Riera, M.; Jover, R. and Caballero, O. (2005), Increased thallium ${ }^{-201}$ uptake and $\mathrm{Tc}^{-99 \mathrm{~m}}$ red blood cell accumulation in hemangioma. Clin. Nucl. Med., 30, 25-26.

Welling, M. M.; Mongera, S.; Lupetti, A.; Balter, H. S.; Bonetto, V.; Mazzi, U.; Pauwels, E. K. and Nibbering, P. H. (2002), Radiochemical and biological characteristics of ${ }^{99 \mathrm{~m}} \mathrm{Tc}-\mathrm{UBI}$ for imaging of bacterial infections. Nucl. Med. Biol., 29, 413-422.

Wong, K. T.; Beauvais, M. M.; Melchior, W. R. and Snyder, S. P. (2004), Enhanced liver uptake of Tc99m-labeled RBCs during gastrointestinal bleed scintigraphy using transfused RBCs compared with autologous RBCs. Clin. Nucl. Med., 29, 522-523.

Wu, R.; Lamontagne, D. and Champlin, J. (2002), Antioxidative properties of acetylsalicylic acid on vascular tissues from normotensive and spontaneously hypertensive rats. Circulation, 105, 387-392.

Zaman, M. U.; Hussain, R.; Sajjad, Z. and Ahmad, M. N. (2004), Localization of upper GI bleed on delayed imaging with ${ }^{99 \mathrm{~m}} \mathrm{Tc}$ tagged RBC angiogram. J. Pak. Med. Assoc., 54, 490-491.
Received: June 30, 2005 ; Revised: July 14, 2005; Accepted: August 01, 2005. 